\title{
Calmodulin independence of human duodenal adenylate cyclase
}

\author{
J A Smith, M Griffin, S E Mireylees, R G Long
}

\begin{abstract}
The calmodulin and calcium dependence of human adenylate cyclase from the second part of the duodenum was assessed in washed particulate preparations of biopsy specimens by investigating (a) the concentration dependent effects of free $\left[\mathrm{Ca}^{2+}\right]$ on enzyme activity, (b) the effects of exogenous calmodulin on enzyme activity in ethylene glycol bis (b-aminoethyl ether) $\boldsymbol{N}, \boldsymbol{N}^{\prime}$-tetra-acetic acid (EGTA) washed particulate preparations, and (c) the effects of calmodulin antagonists on enzyme activity. Both basal $\left(\mathrm{IC}_{50}=193.75\right.$ (57.5) $\mathrm{nmol} / \mathrm{l}$ (mean (SEM)) and NaF stimulated $\left(\mathrm{IC}_{50}=188.0(\mathbf{4 4 . 0}) \mathrm{nmol} / \mathrm{l}\right)$ adenylate cyclase activity was strongly inhibited by free $\left[\mathrm{Ca}^{2+}\right]$ greater than $90 \mathrm{nmol} / \mathrm{l}$. Free $\left[\mathrm{Ca}^{2+}\right]$ less than $90 \mathrm{nmol} / \mathrm{l}$ had no effect on adenylate cyclase activity. $\mathrm{NaF}$ stimulated adenylate cyclase activity was inhibited by $50 \%$ at 2.5 mmol/1 EGTA. This inhibition could not be reversed by free $\mathrm{Ca}^{2+}$. The addition of exogenous calmodulin to EGTA $(5 \mathrm{mmol} / \mathrm{l})$ washed particulate preparations failed to stimulate adenylate cyclase activity. Trifluoperazine and $N$-(8-aminohexyl)-5-IODO-1naphthalene-sulphonamide (IODO 8) did not significantly inhibit basal and $\mathrm{NaF}$ stimulated adenylate cyclase activity when measured at concentrations of up to $100 \mu \mathrm{mol} / \mathrm{l}$. These results suggest that human duodenal adenylate cyclase activity is calmodulin independent but is affected by changes in free $\left[\mathrm{Ca}^{2+}\right]$.
\end{abstract}

Adenylate cyclase is a basolateral membrane enzyme which catalyses the formation of adenosine $3^{\prime}-5^{\prime}$ monophosphate (cyclic AMP) from adenosine triphosphate (ATP). In the intestinal epithelium adenylate cyclase and cyclic AMP are involved in the regulation of water and electrolyte transport, particularly $\mathrm{Cl}^{-}$secretion and $\mathrm{Na}^{+}$absorption. Changes in intracellular free calcium have also been shown to be important in the regulation of intestinal electrolyte transport. ${ }^{1}$ Activation of adenylate cyclase is thought to be important in a number of gut disorders such as the secretory diarrhoea associated with cholera and vasoactive intestinal peptide secreting tumours. ${ }^{23}$ Calmodulin is an ubiquitous intracellular calcium binding protein which influences many enzymic processes. The possible calmodulin dependence of intestinal adenylate cyclase has potential clinical implications as a large number of drugs which are calmodulin antagonists are now well characterised and available - for example, chlorpromazine, trifluoperazine, haloperidol, $\alpha$-adrenergic antagonists, antimalarials, anticholinergics, and antihistamines. ${ }^{4}$ The use of calmodulin antagon- ists as antidiarrhoeal agents, however, has had only limited success in humans. ${ }^{2}$

$\mathrm{Ca}^{2+}$ and calmodulin in some tissues, such as brain, are known to influence adenylate cyclase activity and therefore cyclic AMP production. Several investigators have shown that $\mathrm{Ca}^{2+}$ inhibits the activity of adenylate cyclase at concentrations greater than $1 \mu \mathrm{mol} / \mathrm{l}$ while at submicromolar $\mathrm{Ca}^{2+}$ concentrations activation of the enzyme occurs. It is thought that this activation of adenylate cyclase is mediated by calmodulin but the inhibition of the enzyme by $\mathrm{Ca}^{2+}$ is calmodulin independent. ${ }^{3-7}$ There is now evidence to suggest that some rat, ${ }^{8}$ guinea pig, ${ }^{9}$ and rabbit ${ }^{10}$ intestinal adenylate cyclase activity is $\mathrm{Ca}^{2+}$ and calmodulin dependent.

In brain tissue both calmodulin dependent and calmodulin independent forms of adenylate cyclase have been identified. The calmodulin dependent component can be inhibited by micromolar concentrations of the calcium chelating agent ethylene glycol bis (b-aminoethyl ether) $N, N^{\prime}$-tetra-acetic acid (EGTA).$^{3}$ Furthermore, fluoride ions, which stimulate adenylate cyclase activity by direct activation of the regulatory guanine nucleotide binding proteins, may also help to distinguish the two forms of adenylate cyclase. In vitro the calmodulin dependent form of the enzyme is more responsive to fluoride stimulation than the independent form. ${ }^{11}$

The objective of this study was to assess the importance of $\mathrm{Ca}^{2+}$ and calmodulin in the regulation of adenylate cyclase in the second part of the human duodenum. This was accomplished by assessing (a) the concentration dependent effects of free $\left[\mathrm{Ca}^{2+}\right]$ on enzyme activity, (b) the effects of adding exogenous calmodulin to the adenylate cyclase assay system, and (c) the effects on enzyme activity of the calmodulin antagonists trifluoperazine and $N$ - (8-aminohexyl) -5-IODO-1-naphthalene-sulphonamide (IODO 8), a new naphthalene sulphonamide calmodulin antagonist of improved potency and specificity. ${ }^{12}$ All these parameters were tested on basal and $\mathrm{NaF}$ stimulated adenylate cyclase activity. The results cast doubt on the role of calmodulin in the regulation of human duodenal adenylate cyclase.

\section{Methods}

COLLECTION OF BIOPSY SPECIMENS

Patients presenting at the clinic with diarrhoea or iron deficiency anaemia were biopsied as part of diagnostic investigations to exclude malabsorption. Biopsy specimens of the second part of the duodenum were collected as previously described. ${ }^{13}$ Two specimens were placed in formalin for histological examination to exclude villous 
abnormalities. Those for adenylate cyclase studies were immediately placed in liquid nitrogen. Only specimens from patients subsequently found to have normal histology, who had no underlying upper gastrointestinal disease, and who were not taking any medication were used for these studies. Ethical permission for the study was obtained from the Nottingham City Hospital Ethical Committee and patients gave informed written consent.

\section{TISSUE PREPARATIONS}

The presence of extracellular and intracellular fluids in tissue homogenates has been shown to interfere with adenylate cyclase activity. ${ }^{1+16} \mathrm{We}$ therefore washed biopsy homogenates with a series of homogenisation and centrifugation steps. Four or five biopsy specimens from one patient were homogenised in $2 \mathrm{ml}$ ice cold $2 \mathrm{mmol} / 1 \mathrm{HEPES}$ buffer, $\mathrm{pH} 7 \cdot 5$, containing $5 \mathrm{mmol} / \mathrm{l} \mathrm{MgCl}_{2}$ and $5 \mathrm{mmol} / \mathrm{l} \mathrm{EGTA}(\mathrm{MEH})$ using 10 strokes of a Potter $S$ homogeniser (B Braun) at $1200 \mathrm{rpm}$. The homogenate was made up to $12 \mathrm{ml}$ and was centrifuged at $2500 \mathrm{~g}$ for 20 minutes at $4^{\circ} \mathrm{C}$. The pellet was resuspended in $2 \mathrm{ml}$ fresh $\mathrm{MEH}$ and the homogenisation/centrifugation procedure repeated twice more.

Any large tissue fragments remaining after the second homogenisation were removed. Microscopic examination showed them to be underlying muscularis mucosa and not epithelium ${ }^{17}$ The third pellet was resuspended in $2.4 \mathrm{ml} \mathrm{MEH}$ and homogenised a fourth time using an UltraTurrax (Janke \& Kunkel, Ika-Werk) at maximum speed setting for 15 seconds. Calmodulin may be removed from membrane preparations by washing them in EGTA buffers. ${ }^{5}$ Therefore, in experiments in which no attempt was made to remove endogenous calmodulin EGTA was omitted from the tissue buffer. All buffers were made up in double distilled deionised water or Hipersolv (high performance liquid chromatography grade water).

Cerebral cortex from 2 male Wistar rats were combined and treated as for duodenal biopsy specimens. This washed particulate preparation was used as a positive control to ensure that the assay conditions used were capable of detecting calmodulin dependent adenylate cyclase activity.

\section{ASSAY OF ADENYLATE CYCLASE}

Adenylate cyclase was assayed by the procedure of Salomon et al..$^{19}$ The assay measures the formation of $\left[{ }^{32} \mathrm{P}\right]$ cyclic AMP from $\left[\alpha{ }^{32} \mathrm{P}\right] \mathrm{ATP}$. In a total volume of $100 \mu \mathrm{l}$ the standard reaction mixture contained: an ATP regenerating system of $13 \mathrm{mmol} / \mathrm{l}$ creatine phosphate and $0.1 \mathrm{mg} / \mathrm{ml}$ creatine phosphokinase, $1 \mathrm{mmol} / \mathrm{l}$ ATP labelled with $\left[\alpha-{ }^{32} \mathrm{P}\right] \mathrm{ATP}$ to give approximately $1 \times 10^{6}$ $\mathrm{cpm}$, and $40 \mu \mathrm{l}$ adenylate cyclase assay buffer which consisted of $125 \mathrm{mmol} / \mathrm{l}$ tris-HEPES, $0.25 \%$ bovine serum albumin, $5 \mathrm{mmol} / 1 \mathrm{MgCl}_{2}$ and $2.5 \mathrm{mmol} / 1$ of the phosphodiesterase inhibitor 3-isobutyl-1-methyl-xanthine, at $\mathrm{pH}$ 7.5. For $\mathrm{NaF}$ stimulated activity, reactions also contained $10 \mathrm{mmol} / 1 \mathrm{NaF}$ (originally dissolved in $1 \mathrm{mmol} / \mathrm{l}$ acetic acid). When calmodulin was added to the assay it was dissolved in the adenylate cyclase assay buffer. Calmodulin antagonists (trifluoperazine and IODO 8) were dissolved in dimethyl sulphoxide before addition to the reaction system. Control reaction mixtures contained dimethyl sulphoxide only and final dimethyl sulphoxide assay concentrations were never allowed to exceed $1 \%(\mathrm{v} / \mathrm{v})$.

Reactions were initiated by the addition of approximately $30 \mu \mathrm{g}$ of particulate protein and carried out for 30 minutes at $37^{\circ} \mathrm{C}$. Adenylate cyclase activity was linear up to the maximum conditions tested for time (60 minutes) and protein concentration $(3.9 \mathrm{mg} / \mathrm{ml})$. Reactions were terminated by the addition of $100 \mu \mathrm{l}$ of stopping solution containing: $10 \mathrm{mmol} / \mathrm{l} \mathrm{ATP}$, $1 \mathrm{nmol} / \mathrm{l}\left[{ }^{3} \mathrm{H}\right]$-cyclic AMP $(25000 \mathrm{cpm} / 100 \mu \mathrm{l})$ (to estimate $\left[{ }^{32} \mathrm{P}\right.$ ] cyclic AMP recovery which was $70-90 \%), 2 \%$ sodium dodecylsulphate $(w / v)$, and $50 \mathrm{mmol} / \mathrm{l} \mathrm{Tris}-\mathrm{HCl}$ at $\mathrm{pH} \mathrm{7 \cdot 5}$. Tubes were placed in a boiling water bath for 2 minutes, allowed to cool, and made up to $1 \mathrm{ml}$ with distilled water. $\left[{ }^{32} \mathrm{P}\right]$ cyclic AMP was purified, before liquid scintillation counting, by the double column procedure of Salomon et al. ${ }^{18}$

\section{CALMODULIN ASSAY}

The calmodulin content of the particulate preparations was assayed according to the phosphodiesterase activation method of Thompson et al. ${ }^{2021}$

\section{SUCRASE DETERMINATION}

The brush border enzyme, sucrase, was assayed by the method of Dahlquist. ${ }^{22}$

\section{PROTEIN DETERMINATION}

The protein content of the tissue preparation was determined by Lowry's method ${ }^{23}$ and was normally found to be approximately $1 \mathrm{mg} / \mathrm{ml}$. Bovine serum albumin was used as standard.

\section{CALCULATION OF FREE $\mathrm{Ca}^{2+}$ CONCENTRATIONS}

Contamination of buffered solutions by $\mathrm{Ca}^{2+}$ (up to $20 \mu \mathrm{mol} / \mathrm{l}$ ) necessitates the use of the divalent chelator EGTA in controlling and estimating the free $\left[\mathrm{Ca}^{2+}\right] . .^{2425}$ For each calcium chloride addition the free $\left[\mathrm{Ca}^{2+}\right]$ was computed for ambient $\mathrm{pH} 7$ in the presence of $\mathbf{M g}^{2+}$, EGTA, and ATP using an updated version of the ligandmetal binding program of Feldman et al..$^{26}$

\section{STATISTICAL ANALYSIS}

Where appropriate the Wilcoxon two sample test and the Wilcoxon signed rank tests were used to estimate probability values. Probability values of $<0.05$ were taken as significant.

\section{MATERIALS}

All chemicals were from Sigma Chemical with the exception of $\left[{ }^{3} \mathrm{H}\right]$ cyclic AMP and $\left[\alpha-{ }^{32} \mathrm{P}\right]$ ATP which were from Amersham (UK) and Hipersolv from BDH (Aterstone). The IODO 8 was kindly given by Ian Coutts and Pam 
TABLE I Relative specific activity of sucrase and adenylate cyclase activity in pooled supernatants and particulate preparations of human duodenal biopsy specimens. Results are mean (SEM) from three separate preparations assayed twice

\begin{tabular}{llll}
\hline & & \multicolumn{2}{l}{ Adenylate cyclase } \\
\cline { 3 - 4 } Fraction & Sucrase & Basal & NaF stimulated \\
\hline Homogenate & 1 & 1 & 1 \\
Pooled supernatant & $6.60(0.87)$ & $0.67(0.25)$ & $0.95(0.20)$ \\
Pellet & $0.83(0.02)$ & $1.69(0.32)$ & $2.53(0.09)$ \\
\hline
\end{tabular}

O’Donnell of Nottingham Polytechnic, Nottingham.

\section{Results}

CHARACTERISTIC OF PARTICULATE PREPARATIONS FROM HUMAN DUODENAL BIOPSY SPECIMENS

Table I gives the relative specific activity of the brush border enzyme, sucrase, compared with the basolaterally located adenylate cyclase in pooled supernatants and particulate preparations from three independent tissue preparations. Sucrase activity was enriched in the pooled supernatants and adenylate cyclase activity was enriched in the particulate fractions.

The calmodulin content of the EGTA washed particulate preparations was compared with that of preparations washed in the absence of EGTA to assess the effectiveness of the EGTA washing procedure at removing calmodulin. In brain tissue there was a $25 \%(7 \cdot 49 \mu \mathrm{g} / \mathrm{mg}$ protein to $5.61 \mu \mathrm{g} / \mathrm{mg}$ protein) reduction in calmodulin after washing with EGTA containing buffer. The calmodulin content of the particulate preparation from human duodenal biopsy speci-

Figure 1: Adenylate cyclase concentration response to free $\mathrm{Ca}^{2+}$. NaF stimulated $(A)$ and basal $(B)$ adenylate cyclase activity was assayed in particulate preparations of duodenal biopsy specimens from four patients. Activity was in the presence of 2.5 mmolll ethylene glycol bis (b-aminoethyl ether) $\mathrm{N}, \mathrm{N}^{\prime}$ tetra-acetic acid (EGTA) and $\mathrm{CaCl}_{2}$ at concentrations which gave calculated $\left[\mathrm{Ca}^{2+}\right]$ free as indicated on the abscissa. Each line represents one patient and each data point is the mean of four replicates. Controls were in the absence of added $\mathrm{CaCl}_{2}$ and in the presence of EGTA.

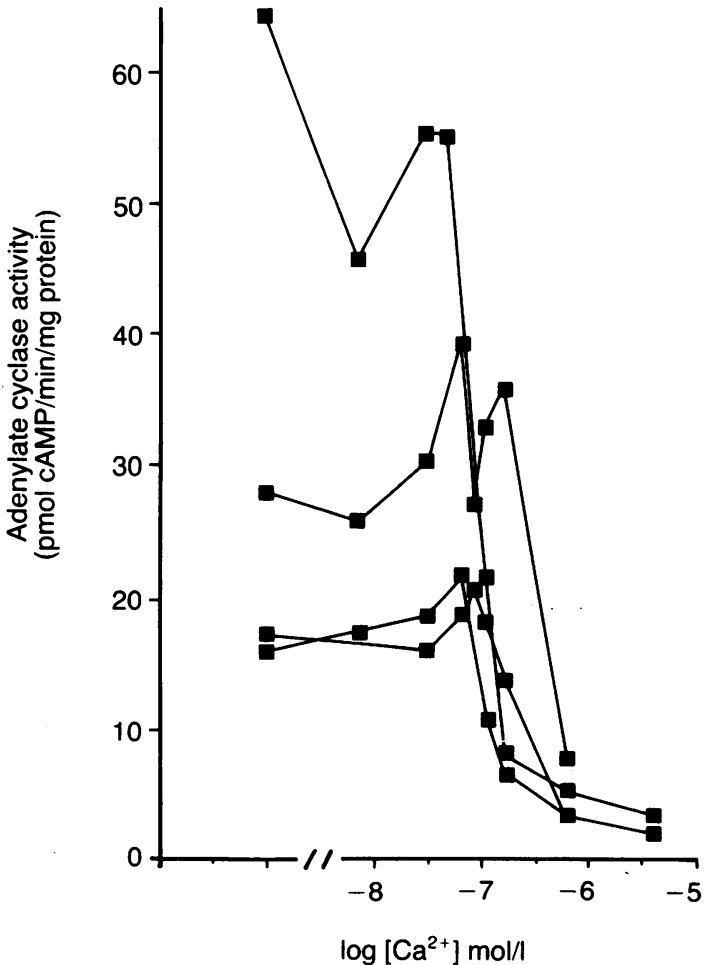

mens, however, was approximately 4-6 $\mu \mathrm{g} / \mathrm{mg}$ protein irrespective of whether the preparation had been washed in EGTA containing buffer or not.

THE EFFECTS OF $\mathrm{Ca}^{2+}$, AND EGTA ON ADENYLATE CYCLASE ACTIVITY

Stimulation of adenylate cyclase activity at low free $\left[\mathrm{Ca}^{2+}\right]$ has been reported to be a good indication of the enzyme's calmodulin dependence. ${ }^{5}$ Therefore, the concentration dependent effects of $\mathrm{Ca}^{2+}$ on adenylate cyclase activity in particulate preparations of human duodenal biopsy specimens was measured. Both basal $\left(\mathrm{IC}_{50}=193.75(57 \cdot 5) \mathrm{nmol} / \mathrm{l}(\right.$ mean $(\mathrm{SEM}))$ and $\mathrm{NaF}$ stimulated $\left(\mathrm{IC}_{50}=188.0(44.0) \mathrm{nmol} / \mathrm{l}\right)$ adenylate cyclase activities were strongly inhibited by free $\left[\mathrm{Ca}^{2+}\right]$ greater than $90 \mathrm{nmol} / \mathrm{l}$ (Fig 1). Free $\left[\mathrm{Ca}^{2+}\right]$ less than $90 \mathrm{nmol} / 1$ neither stimulated nor inhibited adenylate cyclase activity. These data indicate a dramatic reduction in adenylate cyclase activity over a narrow free $\left[\mathrm{Ca}^{2+}\right]$ range.

An alternative way of assessing the importance of $\mathrm{Ca}^{2+}$ in our assay system was to measure the concentration dependent effects of the $\mathrm{Ca}^{2+}$ chelating agent EGTA on adenylate cyclase activity (Fig 2). NaF stimulated adenylate cyclase activity was inhibited by EGTA in a concentration dependent manner with $50 \%$ inhibition at $2.5 \mathrm{mmol} / \mathrm{l}$. Attempts to restore EGTA inhibited adenylate cyclase activity with $\mathrm{Ca}^{2+}$ did not result in a recovery of the enzyme's activity, indicating direct inhibition of adenylate cyclase activity by EGTA. A slight but highly significant increase in basal adenylate cyclase

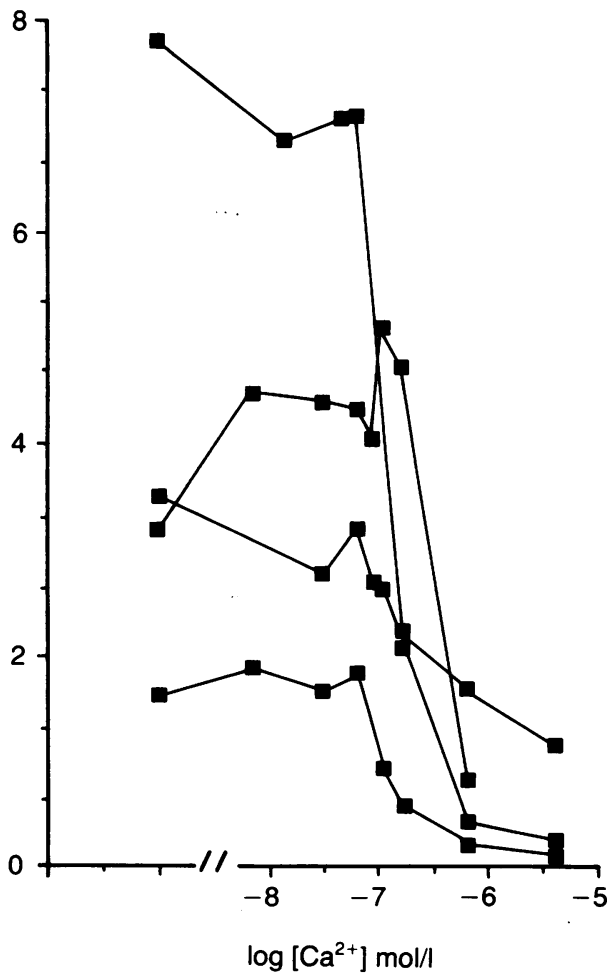




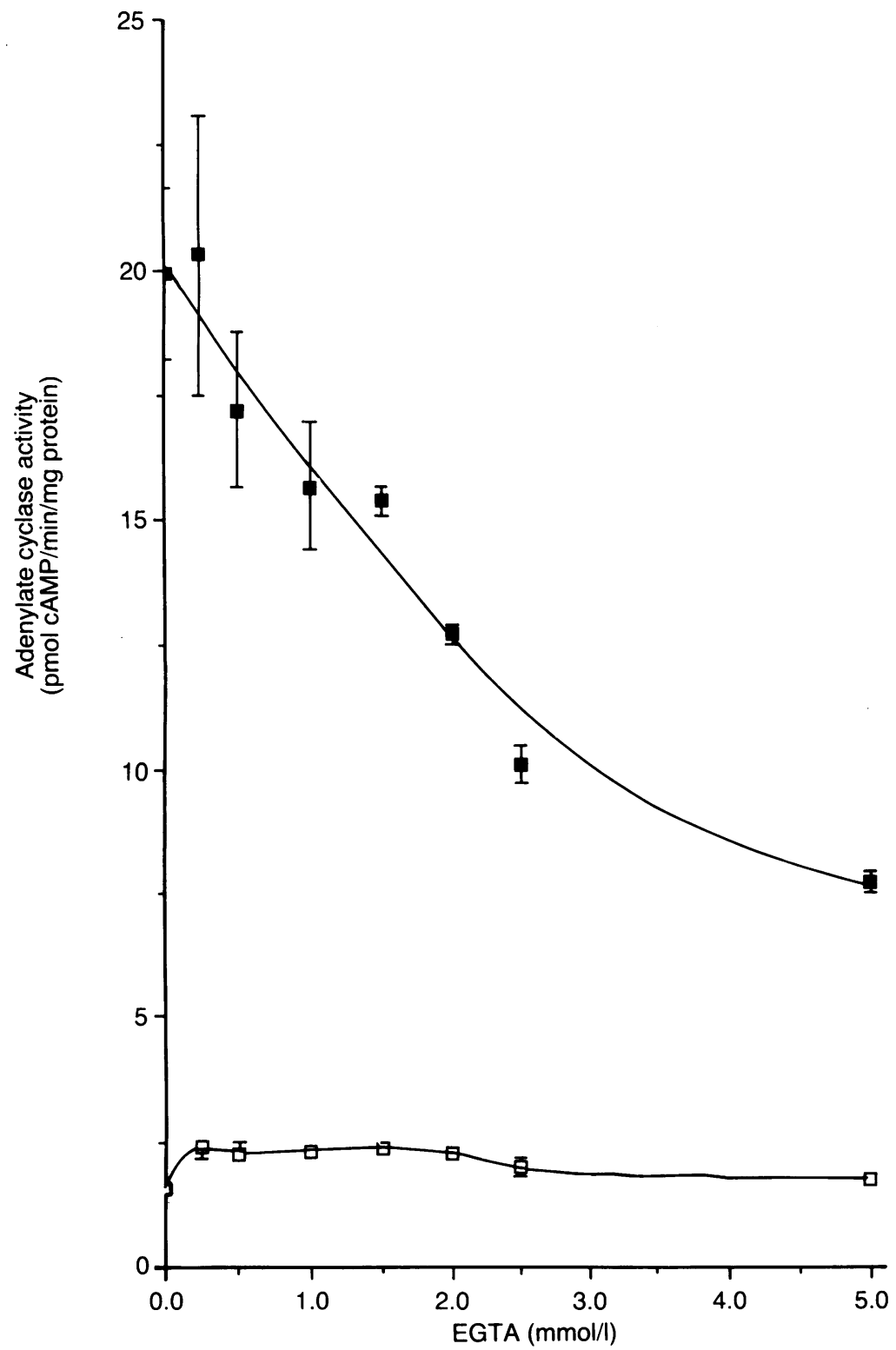

Figure 2: Adenylate cyclase concentration response to EGTA. Particulate preparations of duodenal biopsy specimens were assayed for NaF stimulated ( $\square$ ) and basal ( $\square$ ) adenylate cyclase activity in the absence of added $\mathrm{CaCl}_{2}$ and in the presence of EGTA at the concentrations indicated. Data are the means (SEM) from three experiments - that is, three patients-each with four replicates.

TABLE II Effect of exogenous calmodulin on adenylate cyclase activity in particulate preparation from human duodenal biopsy specimens. Data are the results of three separate experiments each with four replicates

\begin{tabular}{|c|c|c|c|c|c|}
\hline \multirow{2}{*}{$\begin{array}{l}\text { Added } \\
{\left[\mathrm{Ca}^{2+}\right]} \\
(\mathrm{mmol} / \mathrm{l})\end{array}$} & \multirow{2}{*}{$\begin{array}{l}\text { [calmodulin] } \\
(\mu \mathrm{mol} / \mathrm{l})\end{array}$} & \multirow{2}{*}{$\underset{(\mathrm{mmol} / \mathrm{l})}{[E G T A]}$} & \multirow{2}{*}{$\begin{array}{l}\text { Calculated } \\
\text { free }\left[\mathrm{Ca}^{2+}\right] \\
(p \mathrm{Ca})\end{array}$} & \multicolumn{2}{|c|}{ pmol cAMP/min/mg protein $(S E M)$} \\
\hline & & & & Basal & NaF stimulated \\
\hline $\begin{array}{l}0 \cdot 16 \\
0 \cdot 16 \\
1 \cdot 16 \\
1 \cdot 16 \\
0\end{array}$ & $\begin{array}{l}0 \cdot 15 \\
0 \\
0 \cdot 15 \\
0 \\
0\end{array}$ & $\begin{array}{l}2 \cdot 5 \\
2 \cdot 5 \\
2 \cdot 5 \\
2 \cdot 5 \\
2 \cdot 5\end{array}$ & $\begin{array}{l}7 \cdot 76 \\
7 \cdot 62 \\
6 \cdot 52 \\
6 \cdot 52 \\
-\end{array}$ & $\begin{array}{l}3.20(0.29) \\
2.85(0.24) \\
0.54(0.04) \\
0.51(0.05) \\
3.40(0.17)\end{array}$ & $\begin{array}{r}19 \cdot 88(1 \cdot 07) \\
20 \cdot 77(0 \cdot 76) \\
4 \cdot 22(0 \cdot 32) \\
3 \cdot 50(0 \cdot 32) \\
20 \cdot 60(0 \cdot 49)\end{array}$ \\
\hline $\begin{array}{l}0 \cdot 80 \\
0 \cdot 80 \\
0\end{array}$ & $\begin{array}{l}3 \cdot 13 \\
0 \\
0\end{array}$ & $\begin{array}{l}2 \cdot 5 \\
2 \cdot 5 \\
2 \cdot 5\end{array}$ & $\begin{array}{l}6 \cdot 78 \\
6 \cdot 78 \\
-\end{array}$ & $\begin{array}{l}3.72(0.03) \\
3.04(0.08) \\
4.25(0.04)\end{array}$ & $\begin{array}{l}14.98(0.28) \\
13.33(0.45) \\
14.74(0.51)\end{array}$ \\
\hline $\begin{array}{l}0 \cdot 40 \\
0 \cdot 40 \\
0\end{array}$ & $\begin{array}{l}3 \cdot 73 \\
0 \\
0\end{array}$ & $\begin{array}{l}1 \cdot 0 \\
1 \cdot 0 \\
1 \cdot 0\end{array}$ & $\begin{array}{l}6 \cdot 63 \\
6 \cdot 63 \\
-\end{array}$ & $\begin{array}{l}1.36(0.06) \\
1.88(0.03) \\
2.34(0.05)\end{array}$ & $\begin{array}{r}11 \cdot 74(0.12) \\
9.90(0 \cdot 26) \\
18 \cdot 73(0.72)\end{array}$ \\
\hline
\end{tabular}

TABLE III Control experiments in which the effect of exogenous calmodulin on adenylate cyclase activity in particulate preparation of rat cerebral cortex was measured. Data are the results of two separate experiments each with duplicate determinations

\begin{tabular}{|c|c|c|c|c|c|}
\hline \multirow{2}{*}{$\begin{array}{l}\text { Added } \\
{\left[\mathrm{Ca}^{2+}\right]} \\
(\mathrm{mmol} / \mathrm{l})\end{array}$} & \multirow{2}{*}{$\underset{(\mu \text { moll } l)}{\text { [calmodulin] }}$} & \multirow{2}{*}{$\underset{(\mathrm{mmol} / \mathrm{l})}{[E G T A]}$} & \multirow{2}{*}{$\begin{array}{l}\text { Calculated } \\
\text { free }\left[\mathrm{Ca}^{2+}\right] \\
(p \mathrm{Ca})\end{array}$} & \multicolumn{2}{|c|}{ pmol cAMP/min/mg protein $(S E M)$} \\
\hline & & & & Basal & NaF stimulated \\
\hline $\begin{array}{l}2 \cdot 30 \\
2 \cdot 30 \\
0\end{array}$ & $\begin{array}{l}0.61 \\
0 \\
0\end{array}$ & $\begin{array}{l}2 \cdot 5 \\
2 \cdot 5 \\
2 \cdot 5\end{array}$ & $\begin{array}{l}5 \cdot 40 \\
5 \cdot 40 \\
-\end{array}$ & $\begin{array}{l}9.93(4.71) \\
6.32(0.25) \\
5.93(0.09)\end{array}$ & $\begin{array}{l}53.37(10.53) \\
33.48(3.25) \\
17.32(0.26)\end{array}$ \\
\hline $\begin{array}{l}0.90 \\
0.90 \\
0\end{array}$ & $\begin{array}{l}0 \cdot 61 \\
0 \\
0\end{array}$ & $\begin{array}{l}1.0 \\
1.0 \\
1.0\end{array}$ & $\begin{array}{l}5.51 \\
5.51 \\
-\end{array}$ & $\begin{array}{r}18.57(1.32) \\
4.73(1.18) \\
6.72(0.26)\end{array}$ & $\begin{array}{l}51.83(2.61) \\
37.35(3.47) \\
23.94(0.04)\end{array}$ \\
\hline
\end{tabular}

activity was observed at $0.25 \mathrm{mmol} / \mathrm{l}$ EGTA compared with controls; thereafter the curve plateaued up to the maximum concentration tested (5 mmol/l) (Fig 2).

\section{EFFECTS OF EXOGENOUS CALMODULIN ON} ADENYLATE CYCLASE ACTIVITY

The removal of calmodulin by washing membranes with EGTA buffers and the subsequent stimulation of adenylate cyclase activity by adding calmodulin back to the assay system has been shown for several tissues. ${ }^{5}$ No stimulation could be shown in our results from similar experiments using human duodenal biopsy particulate preparations. The addition of calmodulin failed to stimulate adenylate cyclase activity in the presence of various combinations of free calcium, calmodulin, and EGTA (Table II). None of the assay conditions shown resulted in a stimulation of adenylate cyclase activity over controls in the presence or absence of $10 \mathrm{mmol} / \mathrm{l}$ $\mathrm{NaF}$.

The possibility existed that our assay methods were incapable of detecting calmodulin dependent adenylate cyclase activity. We therefore measured adenylate cyclase activity in a tissue well recognised to have a highly active calmodulin dependent component, rat cerebral cortex. ${ }^{3}$ The preparation and conditions of assay for rat cerebral cortex were conducted in exactly the same way as for human duodenal biopsy specimens. This tissue clearly showed the following characteristics: (a) the calmodulin content of the preparation was reduced by $25 \%$ by the EGTA washing procedure used, (b) a biophasic response to calcium (activation followed by inhibition) with a maximum requirement for free $\left[\mathrm{Ca}^{2+}\right]$ of $1-10 \mu \mathrm{mol} / \mathrm{l}$, (c) the addition of $10 \mu \mathrm{g} / \mathrm{ml}$ calmodulin to EGTA wash particulate preparations stimulated adenylate cyclase activity by $30-60 \%$ in the presence and absence of $5 \mathrm{mmol} / 1$ $\mathrm{NaF}$ (Table III). These findings are fully compatible with what is known for brain calmodulin dependent adenylate cyclase. ${ }^{3}$ Verification of the assay methods used was thus established.

\section{EFFECTS OF CALMODULIN ANTAGONISTS ON ADENYLATE CYCLASE ACTIVITY}

The dose dependent effects of trifluoperazine and IODO 8 were examined to establish at what concentration these calmodulin antagonists exerted an influence on adenylate cyclase activity and further to compare the effects of the relatively non-specific trifluoperazine to that of the more specific IODO $8 .{ }^{12}$ By analysis of variance trifluoperazine (Fig 3) and IODO 8 (Fig 4) did not significantly inhibit basal and $\mathrm{NaF}$ stimulated adenylate cyclase activity up to a concentration of $100 \mu \mathrm{mol} / \mathrm{l}$. The $\mathrm{IC}_{50}$ for trifluoperazine of $\mathrm{NaF}$ stimulated adenylate cyclase activity was $225 \mu \mathrm{mol} / 1$ and for basal activity $125 \mu \mathrm{mol} / \mathrm{l}$. Corresponding $\mathrm{IC}_{50}$ values for IODO 8 were 450 and $175 \mu \mathrm{mol} / 1$, however, indicating that the $\mathrm{NaF}$ stimulated adenylate cyclase activity was inhibited less potently than basal activity. This also shows that IODO 8 is less potent than trifluoperazine at directly inhibiting adenylate cyclase activity. These data 


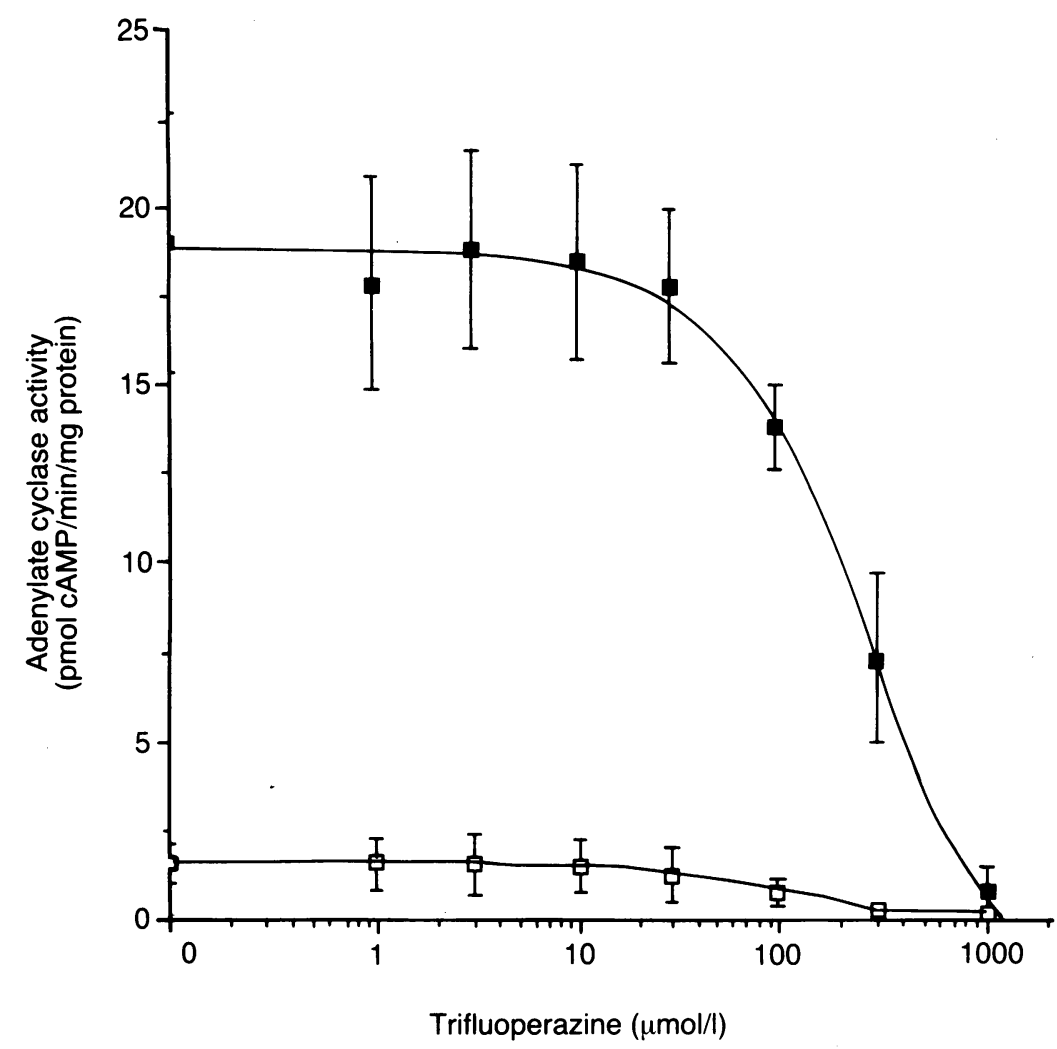

Figure 3: Adenylate cyclase concentration response to trifluoperazine. Biopsy particulate preparations were assayed for $\mathrm{NaF}$ stimulated $(\square)$ and basal $(\square)$ adenylate cyclase activity in the presence of background $\mathrm{Ca}^{2+}$ and the trifluoperazine concentrations indicated. No attempt was made to remove endogenous calmodulin from these preparations. Data are the means (SEM) for three separate patients with four replicates for each trifluoperazine concentration.

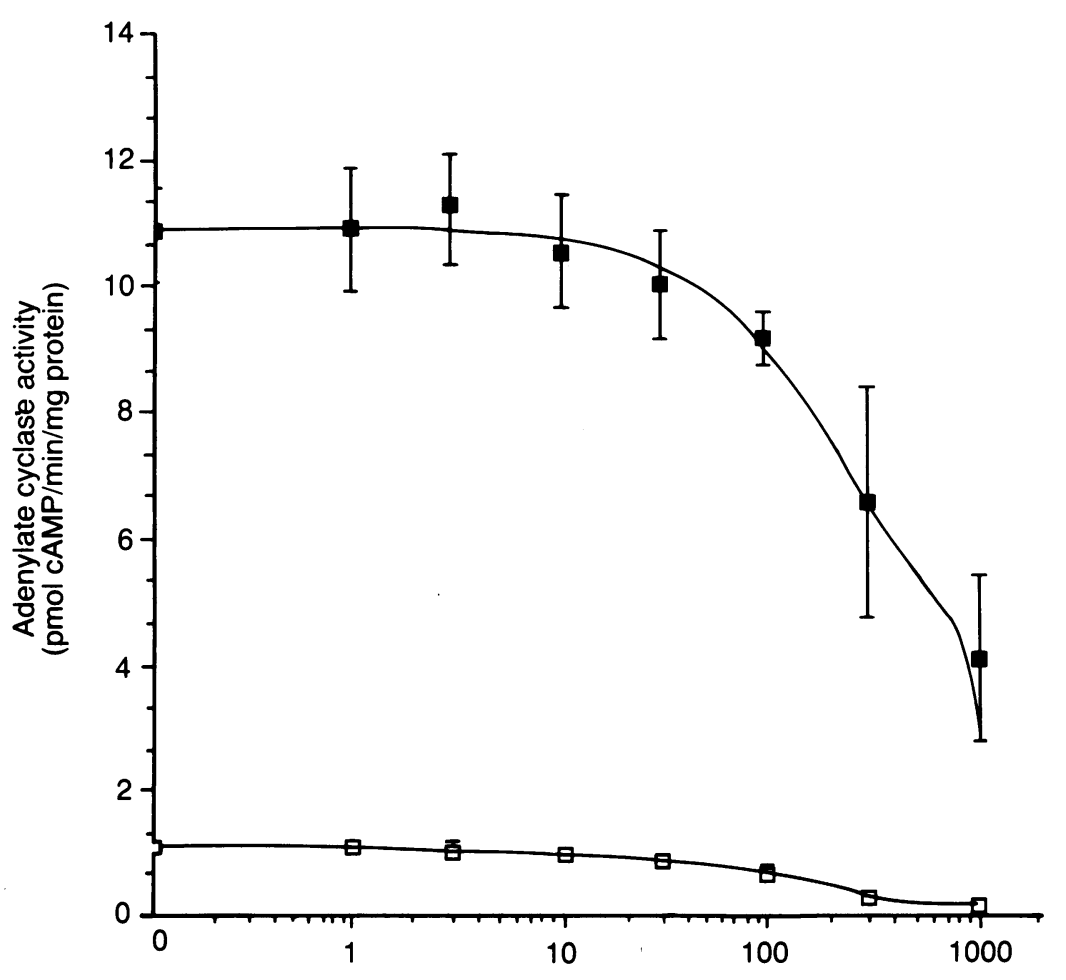

$10008(\mu \mathrm{mol} / \mathrm{l})$

Figure 4: Adenylate cyclase concentration response to N-(8-aminohexyl)-5-IODO-1naphthalene-sulphonamide (IODO 8). Biopsy particulate preparations were assayed for $\mathrm{NaF}$ stimulated ( $(\square)$ and basal $(\square)$ adenylate cyclase activity in the presence of background $\mathrm{Ca}^{2+}$ and the IODO 8 concentrations indicated. No attempt was made to remove endogenous calmodulin from these preparations. Data are the means (SEM) for three separate patients with four replicates for each IODO 8 concentration. suggest that inhibition of basal as well as stimulated adenylate cyclase activity at concentrations of this magnitude represent the non-specific effects of these calmodulin antagonists.

\section{Discussion}

Data presented in this paper suggest that human duodenal adenylate cyclase activity was affected by small changes in free $\left[\mathrm{Ca}^{2+}\right]$. Unlike the intestinal adenylate cyclase from rat, ${ }^{8}$ guinea pig, ${ }^{9}$ and rabbit, ${ }^{10}$ it was calmodulin independent. Evidence to support this comes from a number of our findings. Firstly, we were unable to detect any consistent $\mathrm{Ca}^{2+}$ stimulation of adenylate cyclase activity of a magnitude previously reported in other systems. ${ }^{5810}$ The detection of $\mathrm{Ca}^{2+}$ stimulation of adenylate cyclase is notoriously difficult because it occurs at very low $\mathrm{Ca}^{2+}$ concentrations. Therefore, careful manipulation of free ion concentrations by EGTA buffers is necessary. ${ }^{342425}$

The inhibition of adenylate cyclase activity by EGTA implies a requirement of the enzyme for $\mathrm{Ca}^{2+}$. This effect is only apparent on the $\mathrm{NaF}$ stimulated adenylate cyclase activity which initially suggests that $\mathrm{Ca}^{2+}$ /calmodulin may only be important in the regulation of the stimulated enzyme. The effects of EGTA, however, could not be reversed by $\mathrm{Ca}^{2+}$. This suggests that the chelator may have been inhibiting the enzyme directly and not in a way mediated by $\mathrm{Ca}^{2+}$ chelation and calmodulin inactivation. ${ }^{34}$ The slight increase in basal adenylate cyclase activity at low EGTA concentrations may be the result of the chelation of an unknown inhibiting ion. ${ }^{28}$ The mechanism for $\mathrm{Ca}^{2+}$ inhibition of adenylate cyclase has not been elucidated. Some evidence indicates specific $\mathrm{Ca}^{2+}$ inhibitory sites, ${ }^{29}$ while other evidence implies $\mathrm{Ca}^{2+}$ competition for $\mathrm{Mg}^{2+}$ binding sites. ${ }^{30}$ There is no evidence that the inhibition of adenylate cyclase by $\mathrm{Ca}^{2+}$ is mediated through calmodulin. ${ }^{34}$

Secondly, we were unable to stimulate adenylate cyclase activity in EGTA washed particulate preparations with exogenous calmodulin. This may be explained by the inadequate removal of the endogenous membrane bound calmodulin by buffers containing EGTA. Indeed, the calmodulin content of our particulate preparations from duodenal biopsy specimens was not significantly reduced by the EGTA washing procedure. The levels of calmodulin in our assay system were comparable to those of other workers using animal intestinal membranes and some have shown calmodulin dependence in the presence of endogenous calmodulin at concentrations similar to those in our assay system. ${ }^{89}$ The effective removal of calmodulin from different tissues has been reported to vary considerably. ${ }^{3-5}$ Our data suggest there may also be species differences between the same tissue. This observation has been noted for other tissues, such as heart sarcoplasmic reticulum, ${ }^{31}$ kidney, ${ }^{32}$ and pancreatic islets. ${ }^{33}$

Recent evidence on the distribution of calmodulin in enterocytes indicated that in the human duodenum calmodulin was confined to the soluble fractions and to the brush border membrane; none was detected in the basolateral 
membrane. ${ }^{34}$ This provides indirect support for our findings in that the distribution of human duodenal adenylate cyclase (a basolateral membrane enzyme) is not coincidental with the distribution of membrane bound human duodenal calmodulin. It may be that in our assay system, in which both brush border and basolateral membranes are present, the tightly bound brush border membrane calmodulin becomes available to influence the basolateral membrane adenylate cyclase. But if this were so, and we had been measuring a fully calmodulin stimulated adenylate cyclase system, we would have expected to be able to block the calmodulin effect with calmodulin antagonist (at concentrations specific to calmodulin) and this was not the case. The $\mathrm{IC}_{50}$ for trifluoperazine and IODO 8 were well in excess of those reported for other calmodulin dependent enzymes (6-50 and 3-10 $\mu \mathrm{mol} / 1$ respectively)..$^{1235}$ Interestingly, the distribution of calmodulin in the membranes of rat enterocytes seems to be different from that of human enterocytes. Charpin $e a^{37}$ reported that in rat duodenal basolateral membranes fractions calmodulin could be detected.

Although further investigations are necessary to confirm our findings, these preliminary data indicate that adenylate cyclase in the human duodenal mucosa is calmodulin independent. This implies that increasing the specificity of calmodulin antagonists for use as antidiarrhoeal drugs, which operate through the adenylate cyclase system, would have little pharmacological benefit. It would be interesting to see if human jejunal and ileal tissue adenylate cyclase activity behaves in a similar way.

Financial support for this work by the Trent Regional Health Authority is gratefully acknowledged.

1 Donowitz M, Wicks J, Cusolito S, Sharp GWG. Cytosol free $\mathrm{Ca}^{2+}$ in the regulation of active intestinal $\mathrm{Na}$ and $\mathrm{Cl}$ transport. In: Donowitz M, Sharp GWG, eds. Mechanisms of intestinal electrolyte transport and regulation by calcium, vol 17 . New York: Alan R Liss, 1984: 171-89.

2 Donowitz M, Wicks J, Cusolito S, Sharp GWG. Pharmacotherapy of diarrheal diseases: an approach based on physiologic principles. In: Donowitz M, Sharp GWG, eds. Mechanisms of intestinal electrolyte transport and regulation by calcium, vol 17. New York: Alan R Liss, 1984: 329-59.

calcium, vol 17. New York: Alan R Liss, 1984: 329-59.
3 Shattuck RL, Yeager RE, Storm DR. Calmodulin stimulated adenylate cyclase. In: Cheung WY, ed. Calcium and cell function, vol VII. New York: Academic Press Inc, 1987: 3960 .

4 Minocherhomjee AM, Shattuck RL, Storm DR. Calmodulinstimulated adenylate cyclase. In: Cohen P, Klee C, eds. Calmodulin. Amsterdam: Elsevier, 1988: 249-63.

5 MacNeil S, Lakey T, Tomlinson S. Calmodulin regulation of adenylate cyclase activity. Cell Calcium 1985; 6: 213-26.

6 Walker S, MacNeil S, Tomlinson S. Calmodulin. Br f Hosp Med 1984; 32: 198-201.

7 Tomlinson S, MacNeil S, Walker SW, Ollis CA, Merritt JE, Brown BL. Calmodulin and cell function. Clin Sci 1984; 66: 497-508.

8 Amiranoff BM, Laburthe MC, Rouyer-Fessard CM, Demaille JG, Rosselin GE. Calmodulin stimulation of adenylate cyclase
33-7.

9 Pinkus LM, Sulimovici S, Susser FI, Roginsky MS. Involvement of calmodulin in the regulation of adenylate cyclase activity in guinea-pig enterocytes. Biochim Biophys Acto 1983; 762: 552-9.

10 Lazo PS, Rivaya A, Velasco G. Regulation by calcium and calmodulin of adenylate cyclase from rabbit intestinal epithelium. Biochim Biophys Acta 1984; 798: 361-7.
11 Brostrom CO, Brostrom MA, Wolf DJ. Calcium-dependent adenylate cyclase from rat cerebral cortex. Reversible activa-
tion by sodium fluoride. $\mathcal{F} \mathrm{Biol} C \mathrm{Chem} 1977 ; 252: 5677-85$.

12 MacNeil S, Griffin M, Cooke AM, Pettett NJ, Dawson RA, Owen R, et al. Calmodulin antagonists of improved potency
and specificity for the use in the study of calmodulin and specificity for the use in the study of calmod

13 Smith JA, Mayberry JF, Ansell ID, Long RG. Small bowel biopsy for disaccharidase levels: evidence that the endoscopic forceps biopsy can replace the Crosby capsule. Clin Chim Acta 1989; 183: 317-22.

14 Johnson SK, MacNeil S, Amirrasooli H, Tomlinson S. Effect of extracellular fluid and of cytosol on particulate adenylate cyclase activity. $\mathcal{F}$ Endocrinol 1979; 81: 150-1P.

15 MacNeil S, Crawford A, Amirrasooli H, Johnson S, Pollock A, Ollis $\mathrm{C}$, et al. Stimulation of hormone-responsive adenylate cyclase activity by a factor in the cell cytosol. $\mathcal{F}$ Biochem 1980; $188: 393-400$.

16 Crawford A, MacNeil S, Amirrasooli H, Tomlinson S. Properties of a factor in cytosol that enhances hormonestimulated adenylate cyclase activity. $\mathcal{F}$ Biochem 1980; 188 : 401-7.

17 Tripp JH, Manning JA, Muller DPR, Walker-Smith JA, O'Donoghue DP, Kumar PJ, et al. Mucosal adenylate cyclase and sodium-potassium stimulated adenosine triphosphatase in jejunal biopsies of adults and children with coeliac disease. In: McNicholl B, McCarthy CF, Fottrel PF, eds. Perspectives in coeliac disease. Lancaster: MTP Press, 1978: 461-9.

18 Salomon Y, Londos C, Rodbell M. A highly sensitive adenylate cyclase assay. Anal Biochem 1974; 58: 541-8.

19 Long RG, Bikle DD, Munson SJ. Stimulation by 1,25dihydroxyvitamin $\mathrm{D} 3$ of adenylate cyclase along the villus of dihydroxyvitamin D3 of adenylate cyclase along the vill

20 Thompson WJ, Terasaki WL, Epstein PM, Strada SJ. Assay of cyclic nucleotide phosphodiesterase and resolution of multiple forms of the enzyme. In: Brooker $G$, Greengard $P$ Robison GA, eds. Advances of cyclic nucleotide research, vo 10. New York: Raven Press, 1979: 69-92.

21 MacNeil S, Walker SW, Brown BL, Tomlinson S. Evidence that calmodulin may be involved in phytohaemagglutininstimulated lymphocyte division. Biosci Rep 1982; 2: 891-7.

22 Dahlqvist A. Assay of intestinal disaccharidases. Anal Biochem 1968; 22: 99-107.

23 Lowry OH, Rosenbrough NJ, Farr AL, Randall RJ. Protein measurements with the folin phenol reagent. $f$ Biol Chem 1951; 193: 265-75.

24 Dinjus U, Klinger R, Wetzker R. Ca/EGTA solutions: comparison between measured and calculated free calcium ion concentrations in the micromolar range. Biomed Biochim Acta 1984; 43: 1067-72.

25 Segal J. Cation chelators and their utilization in the preparation of low concentrations of calcium. Biotechnol Appl Biochem 1986; 8: 423-9.

26 Feldman H, Rodbard D, Levine D. Mathematical theory of cross-reactive radioimmunoassay and ligand-binding systems at equilibrium. Anal Biochem 1972; 45: 530-56.

27 Yaseen MA, Pedley KC, Howell SL. Regulation of insulin secretion from islets of Langerhans rendered permeable by secretion from islets of Langerhans rendered

28 Perez-Reyes E, Cooper DMF. Calmodulin stimulation of the rat cerebral cortical adenylate cyclase is required for the detection of guanine nucleotide- or hormone-mediated inhibition. Mol Pharmacol 1987; 32: 212-6.

29 Hanski E, Sevilla N, Levitski A. The allosteric inhibition by calcium of soluble and partially purified adenylate cyclase from turkey erythrocytes. Eur f Biochem 1977; 76: 513-20.

30 Lasker RD, Downs RW, Aurbach GD. Calcium inhibition of adenylate cyclase, studies in turkey erythrocytes and S49 cyc-cell membranes. Arch Biochem Biophys 1982; 216: 34555.

31 Cros G, Molla A, Katz S. Does calmodulin play a role in the regulation of cardiac sarcolemmal adenylate cyclase activity. regulation of cardiac sarcolem

32 Sulimovici S, Pinkus LM, Susser FI, Roginsky MS. Identification of calmodulin-sensitive and calmodulin-insensitive adenylate cyclase in rat kidney. Arch Biochem Biophys 1984; 234: 434-41.

33 Thams P, Capito K, Hedeskov CJ. Differential effects of $\mathrm{Ca}^{2+}$. calmodulin on adenylate cyclase activity in mouse and rat pancreatic islets. Biochem f 1982; 206: 97-102.

34 Stoll R, Stern H, Ruppin H, Domschke W. Effect of two potent calmodulin-antagonists on calcium transport of brush border and basolateral vesicles from human duodenum. Aliment Pharmacol Therap 1987; 1: 415-24.

35 Roufogalis BD. Calmodulin antagonism. In: Marme D, ed. Calcium and cell physiology. Berlin: Springer-Verlag, 1985: Calcium

36 van Os $\mathrm{C}$, Ghijsen WEJ. Mechanisms of active calcium transport in basolateral plasma membranes of rat small intestinal epithelium. In: Gilles-Baillien M, Gilles R, eds. Intestinal transport. Berlin: Springer-Verlag, 1983: 170-83.

37 Charpin MV, Walters JRF, Weiser MM. Detection of calmodulin in basolateral membranes. Gastroenterology 1986; 90: 1370. 